\title{
Tips for permanent education in mental health in primary care guided by the Institutional Socio-clinic*
}

\author{
Larissa de Almeida Rézio $0^{1,2}$ \\ (D) https://orcid.org/0000-0003-0750-8379 \\ Cinira Magali Fortuna ${ }^{3}$ \\ (D) https://orcid.org/0000-0003-2808-6806 \\ Flávio Adriano Borges ${ }^{4}$ \\ (D) https://orcid.org/0000-0001-5941-4855
}

\footnotetext{
* Paper extracted from doctoral dissertation "A educação permanente em saúde para formação em saúde mental na atenção básica, guiada pelos princípios da socioclínica institucional", presented to Universidade de São Paulo, Escola de Enfermagem de Ribeirão Preto, PAHO/WHO Collaborating Centre for Nursing Research Development, Ribeirão Preto, SP, Brazil.

1 Universidade Federal do Mato Grosso, Faculdade de Enfermagem, Cuiabá, MT, Brazil.

2 Scholarship holder at the Coordenação de Aperfeiçoamento de Pessoal de Nível Superior (CAPES), Brazil, and at the Fundação de Amparo à Pesquisa do Estado de Mato Grosso (FAPEMAT), Brazil.

3 Universidade de São Paulo, Escola de Enfermagem de Ribeirão Preto, PAHO/WHO Collaborating Centre for Nursing Research Development, Ribeirão Preto, SP, Brazil.

${ }^{4}$ Universidade Federal de São Carlos, Departamento de Enfermagem, São Carlos, SP, Brazil.
}

Objective: to analyze a process of Permanent Education in Health about mental health with Family Health teams. Method: research-intervention performed with 20 workers from two teams of the Family Health Strategies. Semistructured interviews and 12 reflection meetings were carried out with each team. The principles of Institutional Socio-clinic were used to guide the meetings and the analysis of the data. Results: seven beaconing tips were identified for the Process of Permanent Education in Health: effects produced from the choices of inclusion of the management in the planning of the meetings, revealing established ways of working; attention to non-control in training movements; use of restitution at meetings, reducing stiffness and tensions; attention to the institutions that cross us; analysis of the facilitator's involvement in the training, redirecting behaviors and attitudes; problematization about the object, instrument and purpose, which favored the reflection about the mental health care and to learn to facilitate and experience the Permanent Education in Health in the act of making. Conclusions: socio-clinic assisted the experience of facilitating in-service training, pointing out tips for the collective construction of contextualized, reflexive and problematizing knowledge.

Descriptors: Permanent Education; Professional Training; Public Health; Mental Health; Primary Health Care; Nursing in Public Health.

\section{How to cite this article}

Rézio LA, Fortuna CM, Borges FA. Tips for permanent education in mental health in primary care guided by the Institutional Socio-clinic. Rev. Latino-Am. Enfermagem. 2019;27:e3204. [Access $+\dot{f}$; Available in: DOI: http://dx.doi.org/10.1590/1518-8345.3217.3204. month day year 


\section{Introduction}

The National Health Council (NHC) approved the Training and Development Policy for the Unified Health System (UHS): Pathways to Permanent Education in Health, establishing the National Permanent Education Policy (NPEP) as a UHS strategy for training and work development, considering the constitutional responsibility of the Ministry of Health to order the formation of human resources for the health area(1).

It is understood that the Permanent Education in Health (PEH) is a proposal of relevant learning to contemplate the worker as protagonist of the formation process. The latter - also focused on the problems and difficulties experienced in the daily production of care, management and participation and social control - makes it possible to construct collective spaces for reflection and evaluation of the daily actions of the health services, decentralizing and disseminating the pedagogical capacity between managers and workers, operating in the micro-politics of the work process. In this way, professional training is offered at the same time as the changes in health practices are produced ${ }^{(2-4)}$.

$\mathrm{PEH}$ is one of the strategies that can favor the expansion of mental health care in relation to health services and the care network, as well as highlighting various possibilities of work tools to be used in the psychosocial context, since new policies and guidelines guide the care network and, therefore, involve workers from different services and, necessarily, the Family Health Strategy (FHS), seeking the construction of autonomy and social reintegration of the subjects(5-6).

Despite this indicative of network care, studies indicate that the FHS teams report difficulties in providing care to people suffering from mental illness, referring to the fragility of this specific care and the need for training for $i^{(7-11)}$.

In addition, it is relevant that Mental Health care is also understood in the context of general health, in which the worker acknowledges that the mental health demand can be present in several complaints reported by the users that reach the FHS. Thus, thinking about $\mathrm{PEH}$ as a strategy capable of generating reflective processes and covering mental health care can result in comprehensive care of the person and the family.

Given this context, there is a new demand for the training of workers at work, for work and for the work (12). In order to expand understanding and look at mental health as a care integrated with practice and that takes into account the integrality of the subject, it is necessary that the training be based on the reflection of the work process and that it is a collective construction, not taxation and encompasses psychosocial attention as a guideline.

Although there is this need for training, most of the international studies point to a formative logic still focused on the traditional training and capacities, with measurements of their impacts in the daily work ${ }^{(13-17)}$.

Another relevant point refers to the fact that Mental Health training is often based on the biomedical / psychiatric model, emphasizing the diagnosis of mental disorders and drug treatments, besides happening in a decontextualized way of the daily work of health(18).

Brazil has stood out in terms of training that takes place from the context of health work, dialoguing with it, in a permanent perspective, seeking to propitiate reflection, problematizations, denaturalization of concepts and hegemonic practices in Mental Health, in addition to discussions on the different perspectives regarding psychic suffering and psychosocial attention, incorporation of the discussion of interventions present in the daily routine of the practice as the reception and qualified listening, expanding the ways of caring for the health of the population ${ }^{(19-20)}$.

Given this context, it is understood that the training is not effective to enable the change of practice and the incorporation of new concepts, by de-contextualization and based only on the transmission of knowledge in a unidirectional perspective ${ }^{(3)}$.

Like $\mathrm{PEH}$, one of the structuring axes of Institutional Socio-clinic is also work. For this, the professional practice includes ways of relating to the collective of work, of thinking about these relations and of assigning values, being constituted by a set of updates of the relations that the subjects establish with the professional institution, that is, its professional implications ${ }^{(21)}$.

The institution, in turn, would be the rules and rules established and socially constructed, such as family, education, health, work, among others ${ }^{(22)}$. In this sense, the individual and / or collective subject can problematize his daily work, recognizing himself involved with the aspects and institutions that he questions.

It is believed, therefore, that the Institutional Socio-clinic can act in the perspective of generating $\mathrm{PEH}$ processes. It does not consist in a technical modality or protocol of practice and analysis, but in a way to question the object and intentions of analysis, seeking to understand the social dynamics ${ }^{(21)}$.

Its principles consist of characteristics to be observed in the beaconing of institutional interventions. They are: participation of the subjects in the device; 
analysis of order and demands; analyzer work; application of refund arrangements; analysis of the transformations that occur as the work progresses; intention of knowledge production; attention to contexts and institutional interference, and the analysis of the implications ${ }^{(21)}$.

The devices are elements such as writing, speech, videos, among others, created for / in situations of intervention, that can destabilize the instituted ways of functioning of the institutions, and can also become an analyzer if they can put some situation under analysis, revealing the structure of the institution, provoking it and forcing it to speak $^{(21,23-24)}$.

The order refers to an official request for imaginary solutions or actions to restore order and allows the intervention to begin. It involves not only who asks for the intervention, but also what is asked for ${ }^{(23)}$. The demands are conscious, manifest, deliberate aspects and also unconscious and unsaid aspects, and may be in tune with the order or not. Thus, the order also has individual demands(23,25).

During the analytical process, transformations occur that, for Socio-clinic, deserve attention and attention. In the same way, there are institutional interferences, processes of intersection and noise produced when institutional logics enter into contradiction.

In order for this process to take place, it is necessary to analyze the implications of the researcher and the other participants in the development of socioclinical research. Analyzing the implications is to analyze the relationships that the subjects establish with the institutions that pass through them ${ }^{(26)}$.

Using the principles of Institutional Socio-clinic to mark PEH in Mental Health in the FHS can be a potentiator of learning processes and cause workers to think and reflect on their respective work processes.

Therefore, aiming to answer the research question of how Socio-clinic can enhance the development of $\mathrm{PEH}$ in Mental Health in the FHS this study aims to analyze a process of PEH in Mental Health with FHS teams, guided by the principles of Institutional Socio-clinic, pointing out tips to the development and construction of a critical, reflexive, contextualized and problematizing knowledge.

\section{Method}

Research-intervention based on the theoretical reference of Institutional Analysis - Socio-clinic and carried out from March 2016 to February 2017. The intervention research has the political character of search for transformations from the interrogation of the various senses crystallized in institutions, broadening the theoretical bases and methodologies, in addition to enabling the production of knowledge and new practices at the same time. In this way, the researcher is the subject and object of knowledge(27).

The data presented comprised part of a doctoral thesis whose field of intervention was composed by two FHS of a large municipality of the State of Mato Grosso.

All the workers from the participating FHS, interested in the PEH / Mental Health process, were invited to participate in the intervention research, totaling 20 subjects: eleven workers from team I and nine workers from team II, eleven community health agents ( $\mathrm{CHA})$; two doctors; two nurses; two nursing techniques; two receptionists and a typist. This number fluctuated during the training meetings so that each group had, on average, five to seven people participating.

As an instrument, the semi-structured interview with all workers was used as an instrument, seeking information about daily work, Mental Health practices in the FHS and experiences in PEH. Based on the answers, the analysis and the group reimbursement, themes were included to guide the training sessions in Mental Health. The topics studied were: organizational proposals based on NPEP; psychiatric reform and Mental Health network care; reception and approaches to the user in mental suffering and in use of psychoactive substance; team work; singular therapeutic design; use of tools / scales / tools for Mental Health care and Mental Health care strategies in the FHS. These training meetings were also configured as data production space.

The PEH was guided by the principles of Institutional Socio-clinic with the workers who accepted to participate, totaling 12 meetings, with an average of two hours. The meetings were recorded and transcribed for analysis, protecting the identity of participants.

One also used the researcher's field diary on the intervention research. In this diary, there were reports of group movements, resistances, advances; content discussed, that is, the narrative of the historical-social context reflected in the research activity(28).

As this is an intervention research, the results were discussed with the participants as they were produced. For the organization of the empirical material, the work of transcription was carried out, followed by the transposition, by means of a more attentive and reflexive reading, considering the speeches and the acts / gestures in the different encounters and returning them to the teams. Finally, the work of reconstitution was carried out, in which the construction of a narrative argued around the analysis of the categories ${ }^{(29)}$.

At the reconstitution stage, we sought to identify tips for the experience of a Mental Health training 
through $\mathrm{PEH}$, that is: when analyzing the transcribed material, guided by the principles of Socio-clinic, we sought to separate statements, attitudes, behaviors, actions and postures that could be tips or points of attention to any experience of $\mathrm{PEH}$ and, therefore, be analyzed and discussed with the health professionals who composed this intervention research.

The research was approved by the Research Ethics Committee with the opinion of CAAE No. 53029016.2.0000.5393. The aim was to guarantee the anonymity of the participants and preserve the confidentiality of the information. The speeches were identified by the letter $T$, referring to worker, followed by the randomly chosen Arabic numeration, and the diary of the researcher were indicated with this nomenclature, followed by the month and year.

\section{Results}

The experience in the process of $\mathrm{PEH}$ for the formation in Mental Health points to some beaconing tips guided by the Institutional Socio-clinic.

The first clue is the reflection and attention to the process of making, planning and thinking the $\mathrm{PEH}$, about the instituted way of organizing and planning the trainings and activities in the service, be they graduation, postgraduate or residency activities, since the first device created was the inclusion of the management, by means of the Municipal Health Department, in the process of choosing the units participating in the study, without inserting or consulting these units on their interests in participating, restricting the choice to the Municipal Health Department.

Sometimes this organization and planning become contradictory with the proposal presented by the fact that there is collective participation in decision-making processes from the beginning of intervention planning. Including only management in this process and creating a territory of doubts, fears and longings can lead to participation in the study by obligation, seeking to satisfy management, even as a means to continue being the exemplary service, which meets what is proposed or imposed. The students come here, they start an activity here and then they leave and we have the population to answer (T16); They came from far away to take a photo of the patient and the family is in expectation [...]; comes another student, comes another, at some point, it annoys and does not solve (T20).

These reports provided a reflective look to the health team, shifting from the place already known: the place of teacher. Often, as a teacher, he enters the field of practice, enters the space and territory of the user / family and health team, and then through an administrative reorganization in the distribution of services to universities, it is necessary to change and start the practice in another unit, sometimes performing an irresponsible practice regarding the continuity of care for the other and co-responsibility in this process.

The second clue to PEH is to lose the illusion that there is control and that this is part of the movement to learn concepts, practices and to think collectively. Allowing not to control the learning process is also an important clue to self-management-based training for the collective. What if it does not work out? What if the team does not want to? And if they do not accept it? What if they do not identify with the proposal? Will I account for this process? (Researcher's Journal February /2016)

In this sense, sharing the findings with the participants in a formative perspective centered on the $\mathrm{PEH}$, using the restitution based on the principles of the Socio-clinic, is the third clue presented. The restitution can be an opportunity to pause to look at the process.

The purpose of the restitution was not to pass on information, but to share perceptions with the team, putting them in the analysis. The exercise was to approximate processes of self-management and selfanalysis. But how is this [restitution]? Are you going to tell us what you've written down and what you're thinking? (T16); When students come here, they record, talk, ask, and then walk away; We do not even know anything (T20); It was good that you talked to us about it. We already knew, but did not speak (T19).

The fourth clue would be to look beyond what the person says in the face of situations of tension and tensions in the encounters, paying attention to what their speech carries, what "ghosts", previous experiences, that is, the institutions that cross them. When we began the evaluation of the meeting, I began to return to them about my perception of the group's lack of interest in the delays, demarcations, use of cell phones, among others; naturally, statements were made that resumed restitution. Then, they began to verbalize the obligation to participate in the group (Researcher's Diary August 12016); No one has explained anything to us until you arrive. They called here, they warned you that you would come and that it was something of mental health (T9).

The participation of the management in the indication of the participating units brought a resistance effect to the non-explanation, consultation and discussion in team before the entrance in the field. The team has always experienced the process of heterogeneity, that is, from the control and action of others, in a relationship of vertically hierarchical power. Therefore, attention 
should be paid to what the speech pronounced in the meetings carries.

The implication analysis of the researcher is the fifth clue in which, through this movement, it was sometimes possible to redirect acts and behaviors as the implications were identified.

The entry into the field was initiated on the basis of a misguided and over-implied reasoning that the desire, the ideologies and implications of the researcher were in accordance with the desire, ideologies and implications of the workers and managers. A misunderstanding that may occur in other training experiences centered on the perspective of $\mathrm{PEH}$, which can be redirected from the analysis of implication.

The structural-professional implication with the formation process and with the specialty in Mental Health and the existence of a psycho-affective level with the militancy in Mental Health resulted in fear and insecurity related to the fact of being a teacher of a Higher Education Institution with work in Health Mental. I think I have demanded a lot from this intervention. Required to respond correctly in response to an expectation of the willingness to implement the Psychosocial Care Network, to walk with Psychosocial Care, to involve and bring network workers closer to mental health care (Researcher's Journal May/2016).

As a means of problematizing Mental Health care in the service during the PEH process, the group was offered a discussion about the work process, while a reflection of the daily practices, rethinking the object, instrument and purpose of work in Mental Health from the contributions of Mendes-Gonçalves ${ }^{(30)}$, guiding the formation in Mental Health in the context of work, provoking reflections and provocations on the daily life of these practices, being this the sixth clue for the development of PEH actions. We did our work and did not think about the object, instrument and purpose; I had never stopped to think about it, to reflect, for a year doing my job and I did not even know what I was doing (T13); I go for the visit and often have not even stopped to think about the purpose. [...] now, I keep thinking about the way to the patient's home (T8); My object of work was the disease itself, the madness, because I saw the symptom more [...], now, I cannot think about it $[\ldots]$ in the subject (T3).

And the seventh track is the indication of learning how to facilitate and experience processes of $\mathrm{PEH}$ in the act of doing, taking into account PEH's own perspective that is, putting into action trying to do, in practice, in the daily work. We were going, doing, when he realized, he was already doing Permanent Education. (T19)

\section{Discussion}

It is a challenge to construct and think about effective ways of training workers from their health work context so that decision-making processes are based on the collective so that workers and users actively participate ${ }^{(31)}$. Not recognizing that the organization of the health work process is a result of the inclusion and interaction of workers and users can produce bureaucratic forms of work, with the subjective impoverishment of the worker and, consequently, of the care ${ }^{(32)}$. Thus, the worker may lose his desire for work as he fails to recognize himself in the final product of his work process.

Heterogeneous management can increase the exploitation of labor, alienation, reproduction of the instituted and the naturalization of daily life, and in response to this context, self-managed proposals may arise as an institutional movement ${ }^{(33)}$.

The training process (undergraduate, graduate, residences and in-service training) is not owned by $\mathrm{PEH}$. If the PEH facilitator does not take care of the construction of knowledge in the collective, taking responsibility for the process itself, it can reproduce the instituted way of functioning of the institutions, preventing the unprecedented occurrence ${ }^{(2)}$, as well as the creative and creative power of the collective.

The course of the PEH happens from the movement of the collective, the joint construction, the problematization directed to the needs. Therefore, there is no timetable or lesson plan to follow; there are agreements and directives, based on the principles of NPEP.

The restitution, as an opportunity to deepen or question the analyzes(21), was another Socio-clinic principle used to experience $\mathrm{PEH}$ in the training in service in Mental Health, which also could favor the movement of the collective and the notion of lack of control.

In doing the restitution and sharing of the PEH process in Mental Health, the workers also occupied a place of actors of the learning movement, being able to speak of institutional attitudes and interferences as: to rethink and to talk about the obligation to participate and its relation with behaviors of resistance, stiffness and tension in the encounters.

Looking beyond the behaviors and speeches presented, comprising, therefore, the institutions that cross the professionals, could favor the understanding and resolution of conflicts in the process of formation. In this case, resistance as a barrier to the development of PEH should not be taken as a negative sense, but an opportunity or a way to preserve a certain way of 
working / life in the face of a change of course, as well as possibilities of facing some imposed determinations by management ${ }^{(34)}$.

The principles of Institutional Socio-clinic favored that the facilitator of PEH (and researcher) could interpret this stiffening in the group as a possibility of growth and involvement with in-service training, stimulating instituting processes of self-management.

Being aware of these institutional interferences, such as the fact that municipal management includes services in a taxing way, has opened the possibility for a more powerful meeting. Otherwise, disputes, disagreements and conflicts could be established (35-36).

During the restitution, there was no recrimination or accusations charged with impotent denunciations, but it was used as a space for the enunciation of things, being constructive and respectful(22).

Through the restitution, it was possible to review the demand of the group, understanding that it is changing and does not necessarily happen explicitly. The process of re-discussion of demands was relevant to the analysis of the implication of the researcher and facilitator of $\mathrm{PEH}$, since, from the planning of the research as a member of the Psychiatric Reform and a specialist in Mental Health, she sought to meet a goal of transforming practices service through $\mathrm{PEH}$.

Analyzing these implications with the object of study, based on Socio-clinic, favored new directions and attention for the $\mathrm{PEH}$ process, presenting a great contribution to the PEH facilitator in order to reflect on how the researcher relates to his object of study and work and in what form this interaction takes place analysis of implication ${ }^{(25)}$. The implication can be divided, didactically, into three dimensions: affective-libidinal, related to the affections, of liking or not, of the empathy present or absent between the researcher and the object of study; historical-existential are the world views that carry themselves and structural-professional are the issues related to work ${ }^{(37)}$. Therefore, it was possible to go through auto-analytical processes of analysis of the implication of the researcher with his research, going through the dimensions of this implication.

This understanding of the implications allowed the researcher to understand that the need for control or destabilization against non-control, as presented previously, was related to the implication with her work as a teacher, that is, the teaching institution went through the research. Just as motivated by its ideology and affection with Mental Health care, it remained overmotivated, acting from an objective of implementing Mental Health actions in basic care in articulation with the other services of the health network.
The overlap also experienced is the result of strong ideological engagements ${ }^{(21)}$ - in this context, the militancy and specialization in Mental Health. The objective is not to make the overlap disappear, but to perceive it, to make it visible and analyzable, consequently, no longer acting in the field of overlapping, but of implication, producing a new knowledge(38).

Making PEH for Mental Health training and being concomitantly guided by the principles of Socio-clinic favor spaces and opportunities to re-discuss and revise the needs of the group, revisit the initial proposal and understand that the PEH is a field of dialogue that should also consider the institutional interferences, the diverse implications and desires of all involved.

Another point consisted in using the concepts of object, instrument and purpose, to review the work process. The work process is a means of constructing subjectivities where the subject establishes relationships and (re)produces their existence, having as elements the object, in which the work will be applied, through the use of instruments, which are material or non-material forms (such as knowledge, individual consultation, medicine, among others) in order to achieve a specific purpose ${ }^{(30)}$.

Perceiving these aspects of the work process is also a clue so that one can progress in the transformation of professional practices from the reflective look to the daily life of these.

In this way of learning from the collective, many workers pointed to paths that widened their gaze to the person in mental distress and / or use of psychoactive substance (PAS), while reflecting on the object, instrument and purpose of their job. Thus, $\mathrm{PEH}$, guided by the principles of Socio-clinic, can lead to unlearning, de-territorializations and reflections.

The movement of de-territorialization mobilized by the PEH also traverses this perception about the work, of the institutional implications, that is to say, if one intends to advance in the discussions about what has been produced of effectiveness and power in the care, and the reflection on the clinic, on the work process is relevant and can point to change paths not by the imposition of knowledge or determinations of practices, but by the joint construction of these.

Thus, as the encounters occurred, the team also began to be clear about the proposal, since it also started an active participation in the discussions, planning and evaluations of the meetings, understanding that the facilitator was not in a position to pass on information, but to construct meanings that would transform the practice of health work collectively, resulting in $\mathrm{PEH}$ actions. 
These processes have made the facilitator / worker and the workers face difficult scenes such as: not knowing; do not control; the preconceptions; the exercise of a look at oneself and at one's own practice; to question the reason for certain attitudes routinely committed mechanized, given as natural, generating a certain burden of suffering. In this movement, building the formation from the context, fragilities and potentialities was something powerful and transformative.

Care in Mental Health involves legal-political aspects, training, ethical and political values in which care is centered on the user / family. In considering these aspects, it is no longer possible to think about Mental Health care restricted to medicine, centered on medical knowledge and power and standardized solutions, but based on wholeness, in the context of the subject, in their psychosocial singularity.

That is, the transformation of the look into the work object leads to the creation of new instruments based on inter-sectoral actions that seek the social reinsertion and the autonomy of the users ${ }^{(39)}$. Facing this, it is noticed that the meetings of PEH favored moments of learning to learn, deconstructing and reconstructing new knowledge.

This critical capacity to look at everyday practice and activities with a willing eye to identify fragilities, but also inventions / creations, permeates the process of perceiving reality as being dynamic and fruit of a social and historical construction, which can be transformed(40).

In this sense, $\mathrm{PEH}$ participants began to unveil reality in a movement to look at themselves and practice. Therefore, it consisted in thinking of the movements of PEH as a capacity for outreach, that is, of discovering / producing / welcoming others within ourselves; a multiple singularity, stimulating the capacity of creation, of unfolding, of curiosity before the world, activating the power before the life(41).

As limit of the study, it is pointed out the nondiscussion of results with municipal management. It is considered that the qualitative research does not have the ambition of generalization of results but of the reflections. In this way, it is possible that $\mathrm{PEH}$ takes place from the reality of each day-to-day life, so it is not proposed (and should not be), with this research, to construct a training manual based on the principles and guidelines of the $\mathrm{PEH}$, but point out tips that facilitate its development in the act.

\section{Conclusion}

PEH can be a practice that mobilizes deterritorializations in health work teams as it produces reflection and self-analysis. But it can also be captured by instituted models and by specialized looks for Mental Health as specificity, leading to a more objective, positivist formation with few flexibilities and possibilities of speech or creation in the group and by the group. Thus, it is considered that Institutional Socio-clinic, as a beacon of a process of Mental Health training through $\mathrm{PEH}$, can favor or facilitate movements of looking and perceiving these captures of the instituting forces in daily life.

The Institutional Socio-clinic can potentiate the PEH process, pointing out tips to the formation process that can also be strategies for the production of knowledge in the work and for strengthening the inclusion of the subjects in the collective construction of learning.

It is emphasized that the seven tips presented are not configured as protocols, but are designed to assist facilitators and workers involved in the PEH process. Regardless of the purpose of the training - in this study, the focus is on Mental Health -, the tips are indications to consider the crossings and institutional interferences in health care and, consequently, for training and for the work.

\section{Acknowledgements}

To the professionals of the Center for Psychosocial Care for Alcohol and other drugs, who were part of the process of Permanent Education in Health through occasional discussions, and the professionals of the Family Health Strategies participants.

\section{References}

1. Ministério da Saúde (BR), Agência Nacional de Vigilância Sanitária. Brasília [Internet]. 2009 [Acesso 10 out 2018]. Disponível em: http:// portal.anvisa.gov.br/documents/33856/396770/Po 1\%C3\%ADtica+Nacional+de+Educa\%C3\%A7\%C3 $\% \mathrm{~A} 30+$ Permanente+em+Sa\%C3\%BAde/c92db117e170-45e7-9984-8a7cdb111faa.

2. Fortuna CM, Franceschin TRC, Mishima SM, Matumoto $S$, Pereira MJB. Movements of continuing education in health, triggered by the training of facilitators. Rev. Latino-Am. Enfermagem. [Internet]. 2011 [cited Jul 29, 2018];19(2). Available from: http://www.scielo.br/pdf/ rlae/v19n2/pt_25.

3. Ceccim RB. Continuing education in health: ambitious and necessary challenge. Interface Comunic., Saúde, Educ. [Internet]. 2005 [cited Nov 30, 2017];9(16): 161-77. Available from: http://www. escoladesaude.pr.gov.br/arquivos/File/textos\%20eps/ educacaopermanente.pdf. 
4. Ceccim RB. Permanent Education in Health: decentralization and dissemination of pedagogical capacity in health. Ciênc Saúde Coletiva. [Internet]. 2005 [cited Apr 9, 2018];10(4):975-986]. Available from: http://www.scielo.br/pdf/csc/v10n4/a20v10n4.pdf.

5. Theodoro CM, Moreira MIB. Stories, Our Stories: Powers and Challenges of the World of Work for Users of a Mental Health Service. Mental. [Internet]. 2017 [cited Nov 17, 2018];11(20):279-95]. Available from: http:// pepsic.bvsalud.org/pdf/mental/v11n20/v11n20a15.pdf. 6. Teixeira MR, Couto MCV, Delgado PGG. Primary care and collaborative care in children and adolescents psychosocial interventions: facilitators and barriers. Ciênc Saúde Coletiva. [Internet]. 2017 [cited May 15, 2018];22(6):1933-42. Available from: http:// www.scielo.br/pdf/csc/v22n6/en_1413-8123csc-22-06-1933.pdf.

7. Penido CMF, Castro BP, Coimbra JR, Baker VDSIS, Franco RF. Mental Health in Primary Health Care: Should Matrix Support Be Added or Split? Rev. Polis e Psique. 2018 [cited June 5, 2019]: 8 (1): 33-51. Available from: https://seer.ufrgs.br/PolisePsique/article/view/80415/pdf 8. Eslabao AD, Coimbra VCC, Kantorski LP, Pinho LBSEO. Mental health care network: the views of coordinators of the Family Health Strategy (FHS). Rev Gaúcha Enferm. [Internet]. 2017 [cited June 4, 2019 ]; 38(1): e60973. Available from: http://www. scielo.br/scielo.php?script =sci_arttext\&pid=S198314472017000100418\&Ing=en. Epub May 29, 2017. http://dx.doi.org/10.1590/1983-1447.2017.01.60973.

9. Hanlon C, Fekadu A, Jordans M, Kigozi F, Petersen I, Shidhaye $R$, et al. District mental healthcare plans for five low and middle-income countries: commonalities, variations and evidence gaps. $\mathrm{Br}$ J Psychiatry. 2016 [cited June 7, 2019]; 208 Suppl 56:s47-54. Available from: https://www.cambridge.org/core/services/aopcambridge-core/content/view/6549EABB6B31989 275FDB1F59DC6676D/S0007125000246266a.pdf/ district_mental_healthcare_plans_for_five_lowand_ middleincome_countries_commonalities_variations_ and_evidence_gaps.pdf

10. Sapag JC, Rush B, Ferris LE. Collaborative mental health services in primary care systems in Latin America: contextualized evaluation needs and opportunities. Health Expect. 2016 [cited June 8, 2019 ]; 19(1): 152-69. Available from: https://www.ncbi.nlm.nih.gov/ pmc/articles/PMC5055227/

11. Rigotti DG, Garcia APRF, Silva NG, Mitsunaga TM, Toledo VP. Drug users hosting in a Basic Health Unit. RENE. 2016 [cited June 6, 2019 ]; 17(3):346-55. Available from: http://dx.doi.org/10.15253/21756783.2016000300007
12. Cardoso MLM, Costa PP, Costa DM, Xavier C, Souza RMP. The National Permanent Health Education Policy in Public Health Schools: reflections from practice. Ciênc Saúde Coletiva. [Internet]. 2017 [cited Oct 20, 2018]; 22(5):1489-500. Available from: http://www.scielo.br/ pdf/csc/v22n5/en_1413-8123-csc-22-05-1489.pdf

13. Beurs, DP et al. Evaluation of benefit to patients of training mental health professionals in suicide guidelines: cluster randomised trial. $\mathrm{Br} \mathrm{J}$ Psychiatry. [Internet]. 2016 [cited June 7, 2019]; May; 208(5): 477-83. Available from: https://www.ncbi.nlm.nih.gov/ pubmed/26678866

14. Manning JC, Carter T, Lafit A, Horsley A, Cooper J, Armstrong $M$ et al. 'OurCarethroughOurEyes'. Impact of a co-produced digital educational programme on nurses' knowledge, confidence and attitudes in providing care for children and young people who have self-harmed: a mixed-methods study in the UK. BM] Open. 2017 [cited June 7, 2019]; 7 (4): 147-15. Available from: https:// bmjopen.bmj.com/content/7/4/e014750

15. Mccaffrey ESN, Chang S, Farrelly G, Rahman A, Cawthorpe D. Mental health literacy in primary care: Canadian Research and Education for the Advancement of Child Health (CanREACH). Evid Based Med. 2017 [cited June 7, 2019]; 22 (4): 123-31. Available from: https:// www.ncbi.nlm.nih.gov/pmc/articles/PMC5537558/

16. Patel SR, Gorritz M, Olfson M, Bell MA, Jackson E, Sánchez-Lacay JA et al. Training communitybased primary care physicians in the screening and management of mental health disorders among Latino primary care patients. Gen Hosp Psychiatry. 2016 [cited June 7, 2019]; 38: 71-80. Available from: https://www. ncbi.nlm.nih.gov/pubmed/26598287

17. Jerant A, Lichte M, Kravitz RL, Tancredi DJ, Magnan EM, Hudnut $A$, et al. Physician Training in Self-Efficacy Enhancing Interviewing Techniques (SEE IT): effects on Patient Psychological Health Behavior Change Mediators. Patient Educ Couns. 2016 [cited June 7, 2019]; 99 (11): 1865-1872. Available from: https://www.ncbi.nlm.nih. gov/pubmed/27423177

18. Penido CM, Passos ICF, Andrade, IC. Mental health and family health strategy: first approaching experience. Rev Interinst Psicol. [Internet]. 2015 Dez [citet June 12, 2019 ]; 8(spe): 258-68. Available from: http://pepsic.bvsalud.org/scielo.php?script=sci_ arttext\&pid=S1983-82202015000200008\&lng=pt.

19. Santos AA, Dalla Vecchia M. Workshop Training in Mental Health as a Continuing Education Strategy in Health. Health Soc Change. 2016 [citet June 7, 2019 ]; 7(20): 69-78. Available from: http://incubadora. periodicos.ufsc.br/index.php/saudeetransformacao/ article/view/4044/4549 
20. Santos FF, Ferla, AA. Mental health and primary care in alcohol and drug users care. . Interface. (Botucatu) [Internet]. 2017 Dec [cited June 12, 2019 ] ; 21(63): 833-44. Available from: http://www. scielo.br/scielo.php?script $=$ sci_arttext $\&$ pid $=$ S141432832017000400833\&lng=en. Epub Feb 23, 2017. http://dx.doi.org/10.1590/1807-57622016.0270. $17000400833 \&$ Ing $=$ en

21. Monceau G. Socioclinic techniques for the institutional analysis of social practices. Psicol. Rev. [Internet]. 2015 [cited Nov 7, 2016];21(1):197-217. Available from: http://pepsic.bvsalud.org/pdf/per/ v21n1/v21n1a13.pdf.

22. Loural R. The institutional analysis. $3^{\mathrm{a}}$ ed. Petrópolis: Vozes; 2014. 328 p.

23. Rossi A, Passos E. Institutional analysis: conceptual review and nuances of intervention research in Brazil. Rev EPOS. [Internet]. 2014 [cited Sep 3, 2018];5(1):15681. Available from: http://pepsic.bvsalud.org/pdf/epos/ v5n1/09.pdf.

24. Fortuna CM, Monceau G, Valentim S, Mennani KLE. Socioclinical research in France: notes on Institutional Analysis. Fractal, Rev Psicol. [Internet]. 2014 [cited Nov 5, 2018];26(2):255-66. Available from: http:// www.scielo.br/pdf/fractal/v26n2/1984-0292fractal-26-02-00255.pdf.

25. Baremblitt G. Compendium of institutional analysis and other currents: theory and practice. $6^{\mathrm{a}}$ ed. Belo Horizonte: Record; 2012.

26. Penido CMF. Analysis of implication as a transformation tool in the work process. Gerais: Revista Interinstitucional de Psicologia [Internet]. 2015 [cited Jun 10, 2019 ]: 8(2):248-57. Available from: http:// pepsic.bvsalud.org/pdf/gerais/v8nspe/07.pdf

27. Silveira F, Mishima SM, Matumoto S, Fortuna $\mathrm{SM}$, Bistafa MJ, Bregagnolo JC, et al. Interaction of knowledge for articulation of collective oral health actions: cartography of a Family Health Team. Ciênc Saúde Coletiva. [Internet]. 2014 [cited Oct 23, 2018];19(12):4879-4888. Available from: https:// www.scielosp.org/article/ssm/content/raw/?resource_ ssm_path=/media/assets/csc/v19n12/pt_1413-8123csc-19-12-04879.pdf

28. Pezzato LM, L'Abbate S. The use of diaries as an intervention tool of the institutional analysis: potentializing reflections in the daily life of collective oral health. Physis. [Internet]. 2011 [cited Dec 16, 2017];21(4):1297-314. Available from: http://www. scielo.br/pdf/physis/v21n4/a07v21n4.pdf.

29. Paillé $P$, mucchielli A. L'analyse qualitative en sciences humaines et sociales. 4ème ed. Paris: Armanda Colin; 2016. 424 p.
30. Mendes-Gonçalves RB. Health, society \& history. Ayres JRCM, Santos L, organizadores. São Paulo: Hucitec. Porto Alegre: Rede Unida; 2017. 439 p.

31. Almeida CAL, Tanaka OU. Meta-evaluation of a participatory evaluation developed by municipal health managers focusing on the standard "Utility". Cad Saúde Pública. [Internet]. 2017 [cited Nov 7, 2018];33(2):e00105615. Available from: http:// www.scielo.br/pdf/csp/v33n2/1678-4464-csp-3302-e00105615.pdf.

32. Sutil AD, Lima RCD, Freitas PSS, Felsky CN, Galavote HS. The discourse of the managers of the Family Health Strategy on decision-making in health management: a challenge for the Unified Health System. Saúde Debate. [Internet]. 2015 [cited Oct 22, 2018];39(104): 172-82. Available from: http://www.scielo.br/pdf/sdeb/ v39n104/0103-1104-sdeb-39-104-00172.pdf.

33. Passos E, Palombini AL, Campos RO, Rodrigues $\mathrm{SE}$, Melo J, Maggi PM, et al. Autonomy and cogestión in the practice in mental health: the device of the autonomous management of the medication (GAM). Aletheia. [Internet]. 2013 [cited Jul 30, 2017];41:2438. Available from: http://pepsic.bvsalud.org/pdf/ aletheia/n41/n41a03.pdf.

34. Dobbies DV, L'Abbate S. Resistance as an analyzer of mental health in Campinas (SP): contributions of institutional analysis. Saúde Debate. [Internet]. 2016 [cited Oct 6, 2017];40(110):120-33. Available from: http://www.scielo.br/pdf/sdeb/v40n110/0103-1104sdeb-40-110-0120.pdf.

35. Figueiredo EBL, Silva APA, Abrahão AL, Cordeiro $B C$, Fonseca IA, Gouvêa MV. Effect peroroca in the permanent education in health: on the research-work interaction. Rev Bras Enferm. [Internet]. 2018 [cited Aug 20, 2018];71:1768-73. Available from: http:// www.scielo.br/pdf/reben/v71s4/pt_0034-7167-reben71-s4-1768.pdf.

36. Leite LS, Rocha KB. Permanent Education in Health: How and in what spaces is carried out from the perspective of the health professionals of Porto Alegre. Estud Psicol. [Internet]. 2017 [cited Nov 18, 2018];22(2):203-13. Available from: http://pepsic. bvsalud.org/pdf/epsic/v22n2/a09v22n2.pdf.

37. Barros RBD. Group: the affirmation of a simulacrum. $3^{a}$ ed. Porto Alegre: Sulina/Editora da UFRGS; 2013. (Série Coleção Cartografias).

38. Romagnoli RC. The concept of implication and institutionalist research-intervention. Psicol Soc. [Internet]. 2014 [cited Apr 9, 2018]; 26(1): 44-52. Available from: http://www.scielo.br/pdf/psoc/ v26n1/06.pdf.

39. Silva GM, Zanini DS, Rabelo IVM, Pegoraro RF. The conceptions of what is the psychosocial care 
for mental health professional of a CAPS. Rev Psicol Saúde. [Internet]. 2015 [cited Jun 10, 2019]; 7(2):

161-67. Avaliable from: http://pepsic.bvsalud. org/scielo.php?script=sci_arttext\&pid=S2177093X2015000200010\&lng=pt.

40. Freire P. Awareness: Theory and Practice of Liberation: An Introduction to the Thought of Paulo Freire. 3a ed. São Paulo: Centauro; 2006.

41. EPS em Movimento. Learning and engendering a new field of possibilities: outreach [Internet]. 2014 [cited Feb 1, 2018]. Available from: http://eps.otics.org/ material/entrada-textos-em-cena/arquivos-em-pdf/oaprender-e-o-engendramento-de-um-novo-campo-depossibilidades-outrar-se. Creative Commons (CC BY).

This license lets others distribute, remix, tweak, and build upon your work, even commercially, as long as they credit you for the original creation. This is the most accommodating of licenses offered. Recommended for maximum dissemination and use of licensed materials. 